\title{
LEGAL AND ECONOMIC CONSEQUENCES OF THE ACCIDENTS AT WORK AND OCCUPATIONAL DISEASES IN FRANCE
}

\author{
Czapka Miroslaw', Kontny Urszula²
}

\author{
'Wyzsza Szkola Ekonomii i Administracji w Bytomiu \\ ${ }^{2}$ Gornoslaska Wyzsza Pedagogiczna im. Kardynala A. Hlonda w Myslowicach
}

The paper presents a review of accidents at work and occupational diseases in France as well as their legal and economic consequences. Many countries in the world don't pay enough attention to problems related to safety and hygiene at work. Millions of people work in harmful and unfavourable conditions. Fortunately, in some countries the protection of life and health of the employees take an important place in the national social policy guidelines. France is one of these countries. The authors highlights the most important features of the system of compensation for the loss of health or life in France, with regard to different legal and economic regulations on the consequences of accidents at work and occupational diseases in this country, which are currently implemented in Ukraine and in Poland.

Keywords: accident at work, occupational disease, work-related diseases, consequences of accidents at work and occupational diseases

\section{Introduction}

The healthcare system of the workers in each country differs not only by how long does it function in social policy, but also by its aims, organization, scope as well as way it is financed. It is sufficient to refer to the issue of occupational diseases and it will turn out, that they are not only differently defined in various countries, but also the diseases described as an occupational ones are quite different. A good example can be provided within a list of occupational diseases in Poland and Czech Republic. This system works also quite differently in Germany or in Spain. One should underline, that in the obligatory employees healthcare systems in different countries some areas ore very similar or parallel. This results of the fact that many countries ratified the Conventions of International Labour Organization. Many states also belong to the European Union. As it is known, first laws of European community in the domain of social policy concerned the area of occupational safety and health. The amount of members of the European Union is not constant, but has increased during last decenniums. In consequence, a growing amount of European Union member states the same decrees regulating the questions related to the protection of health and life of the workers are in force. One must underline that a country which applies a membership of the European Union must adapt its national legislation to the European ones during the pre-accession process. It has for consequence the fact that each country, before it officially becomes a member of the European community has already his legislation adapted to the one in force in European Union. It concerns also the legislation related to the occupational safety and health. This situation doesn't concern France, as it was one of the members which founded the European Union.

The data below are elaborated basing on the official statistics of the National Institute of Statistics and Information about the Economy (Institut National de la Statistique et des Etudes Economiques - INSEE) and the National Health Insurance Found for Workers (Caisse Nationale de l'Assurance Maladie des Travailleurs Salaries, CNAMTS), which can be found on the webpage http://www.risquesprofessionnels.ameli.fr

\section{Accidents at work in France}

The article L411-1 of the French National Social Insurance Code [1] defines the accident at work as following: «Is considered as an accident at work, independently of the reason, each accident which occurred within or by the occasion of work, caused by any person employed or working, in any character and in any place, for one or several employers or superiors of enterprise». Point 2 of this article precises that can be considered as an accident at work one which occurs during the road to and from between «primary place of residence, secondary place of residence of permanent character or any other place to which goes the employee for family reasons and the workplace» or then «place of work and the restaurant, canteen or any place where the worker usually eats his meal, 
unless this road has been interrupted or has had a indirect character caused by personal reasons, not connected with everyday life necessities or being independent of work». The Decree no 4126 of the 19th of July 2001 of the Court of Appeal - the Chamber of Work [2] precise that the category «accidents at work» includes also those accidents which occurred during a business trip, independently if they took place while exercising professional tasks or the everyday life activities unless the employer is be able to prove that the injured worker has interrupted [then] the realization of the professional trip for personal reasons. According to the law court's decisions quoted above, an accident at work is characterized by its fortuity and the relation between the unforeseen or fortuitous incident which happened and the executed work. When both conditions are fulfilled, the victim benefits from the presumption of the employer's responsibility. French legislation didn't create a typology of accidents at work, but has implemented a system of tables; these permit to evaluate the state of the injured person which will be considered in the latter part of the present article.

As we could already see, an accident at work occurs due to a random occurrence which can be described as a sudden and violent action of an external factor which results in a bodily injury. It means to be qualify an injury as being a result of accident at work, it must have a determinable beginning and must occur in a definable moment. The rights and obligations of a victim, employer and the opinion of the physician attending the victim as well as those of the Primary Health Insurance Fund has been described in detail in the article L 441 of the National Social Insurance Code [1].

The obligation of the victim is to inform his employer about incident which took place during the 24 hours since the moment when it occurred, if this is not impossible for reasons of cause majeure; such an information can be also made by a person authorized by a victim or one of her collaborators. This declaration can be also presented directly in Primary Health Insurance Fund in the time which doesn't go beyond a limit of two years after the moment when the incident occurred, in case if only after some time it turned out that the incident has caused unforeseen consequences on the health of the victim, or also in situation, when the employer does not want to recognize the accident at work as such. In this declaration the injured person must give information about the place of incident, its circumstance as well as the possible witnesses of the event [3].

The employer submits to the injured person a card of accident at work, so this last can benefit from free medical treatment in consequence of the event, in framework of the existing rate of medical services prices. The injured person has also the duty to deliver to her employer the certificate of sick leave (paid sick days), if she received such from the doctor. If employer denies the fact of appearance of accident at work, then Primary Health Insurance Fund passes to the injured person the card of accident at work [1,3].

The employers duty is to inform the Primary Health Insurance Found, to which belongs the injured person, within 48 hours by means of certified mail with delivery confirmation about the incident; in this form he specifies date, place of occurred incident, its circumstances as well as the identity of possible witnesses of the event. In order to fulfill this formality he can also use the Dematerialized Declaration of the Accident at Work via the service Net - enterprise, http://www.net-entreprises.ir/.

In case if the injured person received from a doctor a sick leave, the employer's duty is to join to the documentation send to the Primary Health Insurance Fund the payroll statement of the injured person. In case if the employer have objections concerning the professional character of the accident, he can formulate them in writing in the declaration send to the Found. Within 20 days he delivers also to the worker the card of accident at work with date in triplicate (so called triptych) in order to justify the medical care costs, even if he denies the existence of the accident at work. For lighter accidents it is obligatory to keep a register, so called the Register of the Health Point which can later be a basis to declare an accident at work which initially seemed to don't have any serious character. The doctor to whom has addressed the injured person fills out the so-called «certificate of initial description» in duplicate. This document has a medical and legal character, therefore it has to describe patient's state in the most exhausting way possible, also in order to determine the presumption of responsibility. In this document the attending physician describes the injured person's state, place and character of suffered health damages together with the description of observed symptoms as well as complications resulting from the patient's state. He informs also about the duration of necessary medical care, as well as of those of the potential sick leave. One of the exemplars is 
passed on to the Primary Health Insurance Found, the second - to the victim.

If the treatment has a more permanent character, it may be necessary to draw up a «Certificate of prolongation», also made in duplicate.

After the end of period of medical investigations, the doctor fills out the «final certificate», in which he marks the date of the patient's return to work with the evaluation of the state of health of injured person according to the following categories:

- recovery with return to the previous state of health

- apparent recovery with possibility of later recurrence of the disease

- stabilization, healing of wounds with complications [3].

All certificates mentioned above are destined to the attention of the doctor - consultant of the national health insurance system. The duty of the mentioned above Primary Health Insurance Fund is to recognize or deny the existence of the accident at work within 15 days, and to inform the Work Inspection about the occurred situation; it has also to realize an administrative and medical interview / inquiry. If the importance of the situation requires it, the Fund notifies the case to the court of first instance. As insuring institution, the role of the Fund is to defray expenses related to the accident at work: benefits in kind (medical care), material services (damages) as well as the evaluation of coefficient of Partial Permanent Disability (Incapacite Partielle Permanente) in case of stabilization (of the health state) with complications. The occurred accident at work will influence on the coefficient of the employer's fee to the national social insurance, which will be determined directly by the Fund [3].

\section{Occupational diseases in France}

Is called occupational disease, according to the article L461-1 of the National Social Insurance Code «every disease indicated in the Table of occupational diseases and which [the person] contracted in accordance to the conditions specified in the table» [1]. According to the points presented in the later parts of the present article of law, if the conditions related to the period of undergo medical care, the time of exposition or the list of executed tasks/activities are not fulfilled, it exists however the possibility to recognize such a disease as having a professional character, provided that the causeeffect relation between the work of the victim and her illness. The legal definition of occupational disease defines it as a consequence of exposition on risk, on which is jeopardized an employee while executing his professional tasks in the framework of his work position. One shall then introduce the distinction between occupational disease and work-related disease:

- this first is an illness which has been inscribed in the list of occupational diseases (so called the MPI list (Maladies Professionnelles Indemnisables $=$ the compensable occupational diseases); in order to recognize it as such, some conditions must be fulfilled as a proper period of time between the detection of the disease and the cessation of the actions causing aforementioned disease, required time of exposition on the injuring factor, the list of actions, which are to be executed (or which were executed) by a worker applying for compensation etc. It is defined as a pathological state being a result of an exposition on some noxious factors in working time.

- work-related disease is described as some pathology being connected with professional activity, but not being inscribed on list of occupational diseases.

According to the French legislation (article L 462-1 of the National Social Insurance Code) [1], the difference between occupational disease and accident at work consists on time of reaction on the situation of exposition at risk : occupational disease is injury / exposure at health risk taking place with time delay, and this exposition on risk can have repeatable character long time before the disease will appear. Accident at work however results in detriment of health directly as a consequence of a concrete event; it takes place in a specified time and place.

French legislation recognize also the existence of diseases being a health complication or result / complication after accident at work. This formula allows to recognize ie. virus HIV infection in the labor time.

As it was already mentioned previously, it doesn't exist in proper term a general definition of occupational disease, but it exists only a collection of conditions which have to be fulfilled, so that a diseases could be recognized as being a result and a consequence of professional activity.

A record of all occupational diseases and being legally recognized as such, can be find in Tables of occupational diseases [4]. They contain a short description of disease, its period of occurrence in relation to the end of tasks being its potential reason, 
as well as the activities and tasks which executing could cause the apparition of the given sickness. First two such lists, in tabular form, were created for the needs of Acts of October 25 th 1919.

These tables are of two types: these related to the so-called general system and those of the specific system for the agriculture-related professions. In total there are 182 tables, in this 118 for general system (numbered from RG1 to RG98) and 64 for agriculturerelated professions (numbered from RA1 to RA57 bis).

The general categories of pathology (health disorders):

- Bronchial, pulmonary and pleural pathologies,

- Cardiologic and vascular pathologies,

- Skin and mucous membranes pathologies,

- Digestive system, gastro - intestinal and hepatic pathologies,

- Contagious and parasitic diseases,

- Infections of an acute course,

- Neurological, muscular and psychiatric pathologies,

- Ocular and vision pathologies,

- Otolaryngologic and stomatological pathologies,

- Bones, joints and periarticular pathologies;

- Kidney, urinary bladder and genitals pathologies,

- Blood and hematopoietic organs pathologies,

- Cancers,

- Others.

In order to qualify a disease as an occupational one and thus subjected to compensations, it must fulfill some definite medical, professional and administrative conditions. They can be found in the aforementioned in previous point lists of occupational diseases [3]. If the disease meets requirements quoted above, it can be qualified as an occupational disease without the necessity of proving by an injured person that it exists a cause effect relation between his work and the illness. Rights and obligations of all the parts participating in the procedure of recognition and declaration of the occupational disease results from the article $\mathrm{L} 461$ of the National Social Insurance Code [1].

The attending physician fulfills «initial medical certificate», which should indicate the type of disease, its clinical and paraclinical symptoms, and also its predictable consequences; this document has to be made in 4 copies, one being meant for the victim.

The employer's duty is to present a declaration to the Work Inspection as well as to the Primary Health Insurance Fund specifying every behavior or procedure which could cause the appearance of the occupational disease. He passes to the injured - that is his worker his payroll statement. These obligations result from the article L 461 of the National Social Insurance Code [1].

The injured person has a legal obligation to present his own declaration up till 15 days after the medical statement given by the attending physician. If during this period the new Journal of Laws including a new list of occupational diseases will be announced, this period will be elongated for 3 months.

In the first stage of the proceedings conduct, the Funds assures itself, that the administrative criteria connected with the recognition of the disease, being on the list of occupational diseases (second and third column) are fulfilled. In this case the occupational disease is recognized as such without the need to provide more proofs. Every doubts are decided in favor of the victim. Then, activities connected with the verification of patient's health state are undertaken:

- physician - consultant of the Fund insures himself if all the conditions related to the disease are conform to the existing list,

- technical control which aim is to ensure that the risk in the enterprise is real.

One of the copies of such records is forwarded to the Work Inspection. If the Fund recognizes the professional character of the pathology, it covers entirely the costs of its treatment in an identical way as in the case of the accident at work. This results from the articles R 441 and L 461 of the National Social Insurance Code [1]. If the Fund does not acknowledge the professional character of a disease, the costs of the medical treatment will be covered by the medical insurance this character (which implies different rate of covering expenses) [3].

\section{Work-related diseases}

As it was mentioned previously, these kind of diseases can be engendered while executing professional activities, but they are not on the list of occupational diseases. Their consequences and frequency of occurrence can be underestimated. Victims of such illnesses are not entitled to get a compensation, but they can however make a demand to the Regional Committee of Recognition of Occupational Diseases which will decide their request. If a disease won't be qualified as an occupational one, it will be covered by the system of medical care. The detailed procedures in such cases are defined by the article L 461 of the National Social Insurance Code [1], the Decree No. 99-323 of April 27 ${ }^{\text {th }}, 1999$ [5], the Circular of the 
National Health Insurance Fund No. 18/99 from May $20^{\text {th }}, 1999$ as well as by the Decree No. 97-950 of October $15^{\text {th }}, 1997$ [6].

The attending physician or occupational medicine physician writes his opinion on special form prepared by the Health Insurance Fund. This document differs from the form which is to be filled out in case of occupational diseases and accidents at work (the same, uniform form exists for these two ones). One of the filled out documents is then transmitted to the doctor of the Work Inspection. This last institution has for function to realize appropriate controls and examination and then, in the next stage, to deliver the all gathered materials to its superior organ, ie. the Ministry of Labour. In France exists the High Council on Occupational Risk Prevention which role is to propose every activities and means aiming to improve the occupational hygiene and safety in the workplace, and also, more generally, the working conditions. The High Council is also consulted about all the legislative projects connected with the prevention of occupational risk, it can also propose to reconsider or extend the existing lists of occupational diseases. The final decision in these matters is undertaken by the Ministry of Labour.

\section{Consequences of accidents at work and occupational diseases}

The French legislation related to the accidents at work and occupational diseases considers only the payment of the compensations related to the physical injuries and the loss of salary (remuneration) caused by the occurred events. The aims of these actions are the following:

- the restoration, within bounds of possibility, to the injured person his ability to work by covering the costs of his treatment, delivering him the necessary equipment, covering the costs of functional rehabilitation as well as the occupational one;

- diminution of the effects of the temporary work cessation by awarding daily damages calculated on a basis different than this of the health insurance;

- ensuring some compensation related to the decrease of physical and professional abilities which can result of accident at work or occupational disease by awarding pension on account of the Partial Disability;

- ensuring, in case of the victim's demise, the financial support for these who were financially dependent of the latter (spouse, children, relatives of the descending line) by awarding them a pension for entitled persons.
Medical care. These issues are regulated by the articles L 442 and R 431 of the National Social Insurance Code [1]. It is covered in $100 \%$, in borders of the limits of the social insurance tariffs, excluding the necessity to advance the payment by the injured person (the costs are directly covered by the adequate institution and not refunded to the injured person after he had to advance the covering of expenses) up to the date of recovery or stabilization. In case of hospitalization, the costs of treatment are fully covered and the victim does not bear the costs of daily sickness benefit. After the stabilization, the medical treatment costs can be covered on account of the accident at work or of the occupational disease under condition, that they will be medically justified, defined and prescribed by the attending physician. He must prepare a protocol of care after consultation with doctor - the consultant of Health Insurance Fund to which belongs the aggrieved person.

In case, when a consensus concerning the protocol of treatment exists, the Health Insurance Fund addresses to the injured person an information about the agreement on covering the costs of medical treatment for the during provided be the medical care protocol. In case of partial agreement or disagreement, the Fund addresses to the victim an information about this decision by a certified mail with delivery confirmation in which are specified the means of appeal against the decision and the period during which it can be lodged. If a further treatment is necessary after the period provided by the protocol, it can be continued or renewed on the demand of the attending physician [3].

Delivery, repair and renovation of the prosthesis and orthopedic equipment are entirely covered, if they appear on the list of products and services provided by the Health Insurance Fund.

The costs of ambulance services, if they are medically justified, are also covered, after previous agreement on this point.

Activities in the domain of occupational readaptation. The injured persons can also benefit from the following activities aiming to maintain them at work:

- part-time work of a therapeutic character, having an aim to gradually return to work. Such application must be submitted by the attending physician, and the work has to begin just after the easing of sick leave;

- functional rehabilitation, which aims to accelerate the renewed adaptation to the professional environment. It can take place in a specialist 
centre or in an independent doctor's consulting room. It is entirely covered and can be also supported by daily damages;

- occupational rehabilitation which aims to help to the injured person to acquire new profession or to re-learn previous ones. This formation can be held in specialized centre. The Fund covers then the costs of formation, accommodation and transport. It can also, after obtaining the opinion of the specialized centre, pay to the injured person a bonus of the end of re-education and grant a loan in order to help to purchase industrial, craftsman's or agricultural equipment. These principles result from the articles L 433 and 323 of the National Social Insurance Code [1].

Daily damages. In case of sick leave, the victim of the accident at work or occupational disease can receive daily damages to the account of the accident at work or occupational disease, however in firsts moment of the duration of the sick leave, these daily damages are paid in the account of health insurance. The daily damages for accident at work or occupational disease will be received only once the professional character of damages and injuries will be explicitly recognized; then a regulation of so far received services can be also considered.

The daily damages are entitled to since the first day of sick leave (in case of «casual» disease - since the $3^{\text {rd }}$ day), without distinction between working days and holidays.

They are granted in the following way:

- the salary for the day in which the accident at work occurred is paid by the employer;

- during first 28 days the going rate equals to the $60 \%$ of a daily rate, which the injured person received according to the last payroll (the last one before the accident). While calculating daily damages are taken in consideration all incomes due to performing professional duties, considering all received salaries, but also the possibly received tips, benefits in kind, but excluding the employer salary costs or the family subsides. The cost of daily damages cannot however exceed the 173,24€;

- during the following period (since 29th day) the injured person can receive daily damages equal to $80 \%$ of his daily rate, but these cannot exceed $230,90 €$.

Those rates are higher than those applied in case of the sick leave for non-professional reasons, however with the limitation that the total income due to daily damages cannot exceed the monthly salary. These sums are tax - free.

Such damages can be also maintained in case of partial return to work with the attending physician's consent, the doctor - consultant of National Primary Health Insurance Fund and the doctor of occupational medicine - in case of described above part-time work of a therapeutic character.

However, to benefit from such service, it is indispensable to fulfill conditions related to the seniority (work record), according to the following principles:

- in case of sick leave lasting less than 6 months, it is necessary to prove that one has worked at least 200 hours during last 3 months previous to the sick leave or that the person has paid social security contributions which amounted at least 1015 of the minimum wage during last 6 months;

- in case of sick leave longer than 6 months, the stay at home has a long-lasting character. It is then necessary to prove that one has worked at least 800 hours during last 12 months, in this 200 hours in the period of first three months or that the person has paid social security contributions which amounted at least 2030 of the minimum wage during last 12 months, in this 1015 during last 6 months. The principles described above are regulated by the articles L 431 and the L 433 of the National Social Insurance Code [1].

Supplementary damages. According to the article L 433 of the National Social Insurance Code, every worker, which has worked in the given enterprise for more than a year has the right to obtain supplementary damages, except for persons working from house, seasonal as well as temporary workers. The job seniority is counted until the first day of sick leave. These damages are received by the injured person from the first day of the absence caused by the occupational disease or accident at work. In case of a non professional disease or non-professional accident, they are received since the 8 th day of absence.

These damages are calculated on the basis of the gross wage of the person, damages received from the Primary Health Insurance Fund included, in the following way:

- during first 30 days, the injured person receives $90 \%$ of her gross wage,

- during next 30 days $-2 / 3$ of gross wage.

This period is prolonged by ten days for every 5 years of job seniority in the given enterprise over the required one year of seniority, however it cannot 
exceed 90 days. In case of consecutive sick leaves, the duration of periods of damages is counted on a 12 months basis and it cannot exceed the quoted above period of damages.

Partial Permanent Disability. The permanent disability can be defined as a definitive loss, partial or total, of the ability to work in the result of an occupational disease or accident at work. In case, when it becomes affirmed, depending of coefficient of disability, the injured person has a right to solicit for a (disability) pension and / or damages in form of capital which amount will depend of the coefficient of disability due to the occurred accident/illness. It is granted in the moment, when the state of the injured will reach the stabilization; its amount is defined by the doctor - the consultant of the Health Insurance Fund. Its aim is to compensate the loss of full health force and the loss of profit which results from this last. The legal regulations concerning this point are enclosed in the National Social Insurance Code (articles L 434 i R 434) [1]. It can be granted in form of the life annuity, if the coefficient of disability is higher than $10 \%$ or in form of capital (single sum), if this coefficient is lower than $10 \%$. It is remitted the next day after date of the patient's stabilization.

While evaluating the patient's state, the doctorconsultant of the Health Insurance Fund takes into attention the following factors [3]:

- type of disability / damage on the injured person's physical integrality: it is the physical or mental health impairment of a person, decrease of its work ability which results from the changes in organs or vital functions of human body;

- person's general state; during the evaluation are not taken into consideration earlier damages or infirmities;

- person's age : during the evaluation the doctor takes into attention the person's organic age, and not only the one resulting from his/her date of birth;

- physical and mental abilities of a person : doctor estimates person's possibilities as well as consequences, which are caused by the repercussions of occurred events on quoted above possibilities of a person ;

- skills and professional qualifications:

Skills are all abilities, capacities which possess the injured person and which can serve to his professional re-classement or to learn a new profession adapted to his current health state.
The professional qualifications are related to the given person's possibilities to execute a given occupation.

Doctor - the consultant of Health Insurance Fund can contact the doctor of occupational medicine in order to obtain some additional information, especially in situations, when the injured person does not seem to be able to continue her previous work.

The amount of the pension obtained as a result of stating the permanent disability is calculated depending on the coefficient of disability and the basic wage, according to the following formula:

The pension $=$ the annual wage $\mathrm{x}$ the coefficient of disability - the coefficient; while calculating annual wage is taken into consideration the wage the person received during last 12 months,

given that when the coefficient is lower than 0,5: annual wage $\cdot$ (coefficient of disability $\cdot 0,5$ ),

when the coefficient is higher than 0,5 : annual wage $\cdot$ (coefficient of disability $\cdot 0,5$ for interval $0-50 \%$ ) (the coefficient of disability $\cdot 1,5$ for values above $50 \%$ ).

So, for example:

- for disability amounting to $20 \%$ : computational coefficient is $20 \% \cdot 0,5=10 \%$; then if the annual wage come to $24000 €$, then the annual pension will come to $24000 \cdot 10 \%=2400 €$;

- for disability amounting to $75 \%$ : computational coefficient is $(50 \cdot 0,5)+(25 \% \cdot 1,5)=62,5 \%$.

If the coefficient of disability is equal or bigger to $80 \%$, the pension is increased of additional $40 \%$ in situation, when the person is forced to have a third party's help in order to accomplish everyday life's activities. This additional sum, being an financial aid for financing third party's help, contrarily to the pension of the Partial Permanent Disability, has a lifelong character. This sum becomes temporarily suspended in situations, when the hospitalization of its beneficiary lasts longer than 45 days. In case, when the disability is equal or higher to $66,66 \%$, the injured as well as his entitled family members can benefit from a total covering of the costs of medical treatment, what means that they don't have to pay the $10 \%$ of extra charge to the services of medical care.

The coefficient of disability is counted on the basis of two separate tables, one concerning the accidents at work (Table for calculating the degree of disability caused by accidents at work) and the second designed for occupational diseases (Table for calculating the degree of disability caused by occupational diseases). 
Pensions are paid once in trimester, when the coefficient of disability is equal or lower than $50 \%$ and for the higher rates - monthly.

If a person possesses already one coefficient of Partial Permanent Disability, to calculate the new coefficient is not used simple addition, but arithmetic system called Baltazar's method. The basis of this method is that the disability which appears after the first one is counted in reference to the remaining ability.

Therefore for example:

in result of the first accident of work the coefficient of disability was estimated on $5 \%$

$=>100 \%-5 \%=$ ability stayed at $95 \%$

in result of the second accident at work the coefficient

of disability was estimated on $7 \%$

$=>7 \%$ from $95 \%=7,36 \%$

the new disability to work will be the following:

$95 \%-7,36 \%=87,64 \%$; accumulated coefficient will go be then $(100 \%-87,64 \%)=$ $12,36 \%$.

The Health Insurance Fund informs the patient about the coefficient of the Partial Permanent Disability which has been attributed to him in official writing. The appeal from the decision of the Fund is possible up to 2 months; the settling instance is the Court of Justice of controversial matters of the permanent disability.

The damages paid in form of capital, for the disabilities smaller than $10 \%$ are as following [8]:

\begin{tabular}{|c|c|}
\hline $\begin{array}{c}\text { Coefficient of Permanent } \\
\text { Disability }\end{array}$ & Damages \\
\hline $1 \%$ & $385,10 €$ \\
\hline $2 \%$ & $625,90 €$ \\
\hline $3 \%$ & $914,62 €$ \\
\hline $4 \%$ & $1443,55 €$ \\
\hline $5 \%$ & $1828,69 €$ \\
\hline $6 \%$ & $2261,78 €$ \\
\hline $7 \%$ & $2742,79 €$ \\
\hline $8 \%$ & $3272,31 €$ \\
\hline $9 \%$ & $3849,74 €$ \\
\hline
\end{tabular}

These damages have a fix character, which means that they ares independent from injured person's income; what is regulated by the decree № 2002420 from March $28^{\text {th }}, 2002$ [8].

This pension doesn't have the character of a retirement pay, because - as we have seen - it has a lifelong character. Yet there exist a possibility of submitting an application in order to ensure its transitivity on a third part; in this case its amount is lowered, as for the financial aid for third part's help. This person must however submit an application for retirement pension which is entirely independent from the pension. This retirement pension can then be transferred on the living spouse after the death of the injured person.

If the injured will consider, that his health state has deteriorated, he has a possibility to apply for revision of his health state, according to the regulations concerning the accidents at work and occupational diseases described in previous parts of the article.

The pension for entitled family members. Spouse, cohabitee or a person connected to the injured person by the civil solidarity pact in case of the death of mentioned above person has a right to receive life annuity amounting $40 \%$ of the annual pension or professional disease, under condition, that their relationship has been contracted before the appearance of the accident at work, lasted more than 2 years in the moment of injured person's death or also, that the couple have an offspring. The amount of the of life annuity can be enlarged of $20 \%$, when the partner reaches the age of 55 years or has been touched by the partial disability of above $50 \%$. If they dead person has divorced, his ex spouse(s) has a possibility to apply for life annuity if they have been awarded of alimonies; in such situation the amount of the pension is equal to the amount of alimonies, but it cannot exceed $20 \%$ of annual salary of the deceased injured person.

Legitimate and adopted children, as well as the illegitimate ones, whose paternity has been legally acknowledged, can also receive pension until they achieve $20^{\text {th }}$ year of life. This pension amount to $25 \%$ of the annual wage of the deceased parent for the first two children, $20 \%$ it for the following, and for the full orphans $-30 \%$.

Ascendant relatives can also apply for life annuity being equal to $10 \%$ of the annual wage of the deceased, if they were previously maintained by him; in the case, when there are of more of such a relatives the total amount granted for the all of them cannot exceed $30 \%$ of the annual wage of the deceased, so in case of necessity it is proportionally reduced for every entitled person.

Gross negligence (inexcusable fault) of the employer. The accident at work or occupational disease will be treated as result of employer's gross negligence, since the moment when this last had or should have consciousness of the risk/threat on which 
were subjected his employees and despite of this did not undertake any suitable means in order to protect them from these. As a special French particularism one should doubtlessly treat the fact, that till the year 2002 the notion of employer's gross fault functioned in the French National Social Insurance Code, but did not become defined up till now; the definition in use so far was from 1941. This notion has been however defined in a precise way by the Social Chamber of the Court of Appeal while one of their judicial sentences, modifying by the same occasion the kind of obligation related to the safety which are incumbent on the employer according to the article L $230-2$ of the Labour Code [9]. Since then, the employer is submitted to the obligation of assuring safety by its results, and every failure from this will be treated as inexcusable fault. Two factors sufficient to affirm the gross fault are: the consciousness of danger which had or should have the employer as well as the lack of undertaken means aiming to prevent the risk quoted above.

Weight of proof of the employer's gross negligence rests on the worker or on his entitled family members whose have to demonstrate that the employer who had the consciousness of risk on which he exposed his workers, did not undertake the indispensable means to prevent this menace. The gross negligence of the employer is then the failure to assure safety of work to his workers. The person injured in the accident at work or as a result of an occupational disease can address a request for acknowledging the employer's gross fault to the Primary Health Insurance Fund since the moment, when the professional character of her disease / accident was recognized, what is the condition sine qua non of the claim. To address such a claim the injured person has 2 years from the date of recognition of the professional character of the health impairment. Such a claim has a character of legal petition of the employer or his substitute, therefore the Fund arranges the trial of private arrangement between the parties. This process is interrupted in case, when an agreement is worked out and becomes the agreement of sides. In the opposite case the worker will appeal to the Court of Justice of social protection [3].

Recognition of the gross negligence of the employer can effect in augmentation of the injured person's pension. Independently of this, the victim can solicit the employer to obtain the compensation for the damages caused by physical or psychical sufferings, those connected with personal aesthetics as well as those resulting in loss or decrease of the possibilities of professional promotion.

If to the injured person was attributed the coefficient of Partial Disability equal to $100 \%$, she will receive additional damages amounting the minimum wage calculated in the moment of stabilization of the person's state. If this accident caused person's death, the entitled family members and also descendent and ascendant family members who don't receive any pension (related to the injured person's decease) can solicit the deceased person's employer for reparation of punitive damages. In both cases this indemnity will be paid by the Fund, which further will recover this amount due from the employer.

The consequences of recognition of the gross negligence of the employer are both financial and legal. Employer has to bribe an additional fee connected to the safety of work in enterprise, and also additional fee increase which is destined to fund the most of the amount of the injured person's pension. He will also have also to pay back damages, what Fund has paid to the victim and which are connected to the aesthetical damages.

Such an accident can also result in penal sentence for the employer - in case of mortal consequences of the accident at work, he can be judged for involuntary homicide.

\section{Conclusion}

As it was indicated in the introduction, in different countries the accidents at work and occupational diseases can be defined in various ways. The present article exposed how these notions are presented in France. Performing the comparison of the French way of apprehending the accidents and diseases related to executing professional activities, the authors have compared them to the definitions presented in their previous articles published in the «Medicine of Work», concerning the legal and economic consequences of accidents at work and occupational diseases in Poland as well as in Czechia. We can notice significant differences in the system of recognition, but also of funding these unfavorable events. Thanks to the comparison of systems of worker's protection in case of appearance of these pathological situations in the workplace, it is possible to adopt the most suitable solutions for the needs of the national system of health protection as well as for the workers' life. 


\section{Bibliography}

1. National Social Insurance Code (Code de la securit? sociale), http://www.legifrance.gouv.fr/affichCode. do?cidTexte $=$ LEGITEXT000006073189\&dateTexte $=$ 20101119

2. Decree no 4126 of the 19th of July 2001 of the Court of Appeal - the Chamber of Work, http://www.lexinter. net/JPTXT/accident_du_travail_en_mission.htm

3. Official state page "Accidents at work and occupational diseases" http://www.risquesprofessionnels. ameli.fr/fr/accueil_home/accueil_accueil_home_1.php

4. Tables of occupational diseases, http://inrsmp. konosphere.com/cgi-bin/mppage.pl?state $=1 \&$ acc $=$ $5 \& g s=\& \operatorname{rgm}=2$
5. Decree No. 99-323 of April 27th, http://www. legifrance.gouv.fr/affichTexte.do?cidTexte = JORFTEXT $000000760103 \&$ dateTexte $=$

6. Decree No. 97-950 of October 15th, 1997, http:// droit.org/jo/19971018/MESS9722331D.html,

7. Table for calculating the degree of disability caused by accidents at work and occupational diseases, http://vosdroits.service-public.fr/F14854.xhtml

8. Decree No. 2002-420 from March 28th, 2002, http://droit.org/jo/20020330/MESS0220611D.html

9. Labour Code, http://www.legifrance.gouv.fr/ affichCode.do?cidTexte = LEGITEXT000006072050\& dateTexte $=20101119$

\section{Мирослав Чапка ', Урсула Контни² \\ ЮРИАИЧЕСКИЕ И ЭКОНОМИЧЕСКИЕ ПОСАЕАСТВИЯ НЕСЧАСТНЫХ САУЧАЕВ НА РАБОТЕ И ПРОФЕССИОНАЛЬНЫХ ЗАБОЛЕВАНИЙ ВО ФРАНИИИ}

' Высшая школа экономики и администрашии в г. Бытом

2 Горноселезская высшая педагогическая школа им. Кардинала А. Блонда в Мысловичах

В статье представлен обзор несчастных случаев на рабочем месте и профессиональных заболеваний во Франции, а также их юридические и экономические последствия. Во многих странах мира проблемам безопасности и гигиены на рабочем месте уделяется недостаточно внимания. Миллионы людей работают во вредных и неблагоприятных условиях. Однако, в некоторых странах, защита жизни и здоровья работающих занимает важное место в документах национальной социальной политики. Франция является одной из таких стран. Авторы раскрывают наиболее важные черты системы компенсации за потерю здоровья или жизни во Франции, с учетом различных юридических и экономических регулирующих документов о последствиях несчастных случаев на работе и профессиональных заболеваний в этой стране, и которые внедряются в настоящее время в Украине и Польше.

Ключевые слова: несчастные случаи на рабочем месте, производственно-обусловленные заболевания, последствия несчастных случаев на рабочем месте и профзаболеваний

\section{Мирослав Чапка', Урсула Контни²}

\section{ЮРИАИЧНІ ТА ЕКОНОМІЧНІ НАСАІАКИ НЕШАСНИХ ВИПААКІВ НА РОБОЧОМУ MICU ТА ПРОФЕСІЙНИХ ХВОРОБ У ФРАНUÏ}

${ }^{1}$ Виша школа економіки і амміністрашії в м. Битом

2 Горноселезька виша педагогічна школа ім. Кардинала А. Блонда у Мисловичах

Наведено огляд нещасних випадків на робочому місці та профзахворювань у Франції, а також їхні юридичні та економічні наслідки. У багатьох країнах світу недостатньо уваги приділяється безпеці та гігієні на робочому місці. Мільйони людей працюють у шкідливих та несприятливих умовах. Але в деяких країнах захист життя та здоров’я працюючих займає важливе місце в документах національної соціальної політики. Франція є однією з таких країн. Автори розкривають найбільш важливі особливості системи компенсування за втрату здоров'я або життя в цій країні, з урахуванням різних юридичних та економічних регулюючих документів, що стосуються наслідків нещасних випадків на робочому місці та профзахворювань у цій країні, і які впроваджуються зараз в Україні та Польщі.

Ключові слова: нещасні випадки на робочому місці, профзахворювання, виробничо-зумовлені захворювання, наслідки нещасних випадків на роботі та профзахворювань

Author: M. Czapka is a full Professor at Silesian College of Economy and Administration in Bytom, PL 41-902 Bytom, Poland. E-mail: rektorat@gwsp.pl 